\title{
The Interplay between the Verbal and Visual in Outdoor Interpretive Panels
}

\author{
Šarolta Godnič Vičič \\ University of Primorska, Faculty of Tourism Studies - Turistica, Slovenia \\ sarolta.godnic.vicic@gmail.com
}

Nina Lovec

University of Primorska, Faculty of Tourism Studies - Turistica, Slovenia

nina.lovec@fts.upr.si

\author{
Ljudmila Sinkovič \\ University of Primorska, Faculty of Tourism Studies - Turistica, Slovenia \\ milka.sinkovic@fts.upr.si
}

Outdoor interpretive panels inform visitors about the features of a heritage site and the events and objects they encounter during their visit with the aim of improving their awareness and understanding of the site. In addition to having this educational role, interpretive panels are also regarded as a means of enhancing visitor experience and the quality of natural or cultural heritage sites - especially since the information on these signs is available at all hours and can be accessed by large numbers of visitors. Various disciplines have treated outdoor interpretive panels as communication and a form of product development, highlighting topics such as visitors' use of interpretive panels, strategies for capturing and holding visitors' attention, the effective conceptual design of interpretive panels, their efficiency in educating visitors and enhancing visitor experience, and others. This study will focus on outdoor interpretive panels in natural sites. To deliver their message, interpretive panels combine verbal and visual information. The analysis of the intersemiotic logical relations between them aims to reveal the ways in which the two modes interplay in interpretive panels and create cohesive messages through logical relations.

Keywords: heritage interpretation, outdoor interpretive panels, textual-visual intersemiosis, intersemiotic cohesion, intersemiotic logical relations

https://doi.org/10.26493/2335-4194.11.161-17o

\section{Introduction}

Outdoor interpretive panels ${ }^{6}$ are a form of non-personal interpretation that most frequently offer textual and visual interpretive contents to visitors in natural and cultural heritage sites. Since interpretive panels do not

${ }^{6}$ In the relevant literature, interpretive panels are interchangeably referred to as 'interpretive' or 'interpretation boards', 'signs' or 'signage', or 'wayside exhibits'. require an interpreter to share their contents, visitors are free to read them or not. If they decide to read the texts and view the visual materials on display, they can do so in any order they prefer; moreover, they can read all the text and view all the images or only some of them (Ham, 2013; Smaldone, 2013; Ward \& Wilkinson, 2006). This freedom of selective reading and viewing, however, may come at a price: visitors may overlook parts of the messages the creators of the 
panels intended them to read (Smaldone, 2013; Ward \& Wilkinson, 2006). While there is ample literature reporting on the effects of the placement decisions of interpretive panels (Hall, Ham, \& Lackey, 2010; Ham, 2013; Light, 1995; Smaldone, 2013) and highlighting the principles for designing effective texts for interpretive displays both in heritage sites (Hall et al., 2010; Ham, 2013; Light, 1995; Smaldone, 2013; Ward \& Wilkinson, 2006) and in museums (Fritsch, 2011; Hillier \& Tzortzi, 2006; Moser, 2010; Psarra, 2005), little has been said about the interplay between texts and visuals in outdoor interpretive panels. The aim of this paper, therefore, is to address this gap by exploring the intersemiotic relations between the verbal and visual semiotic resources in interpretive panels and their cohesive ties with each other. Using a multimodal approach, this paper will analyse an interpretive panel from a protected nature reserve, the Strunjan Natural Park in Slovenia, in greater detail.

We begin the next section with a brief review of heritage interpretation, outdoor interpretive panels and intersemiosis. The rationale for the choice of methods is then presented as well as the intersemiotic relations found in the outdoor interpretive panel. We conclude the paper with a discussion of the implications of our results.

\section{Heritage Interpretation}

While the roots of heritage interpretation have been traced back to the times of storytellers and bards (Brochu \& Merriman, 2002) as well as to ancient travel journals and stories told by the first tourist guides 4000 years ago (Silberman, 2013), heritage interpretation as a profession and object of academic inquiry is of a more recent origin. Disciplines such as geography, education, sociology, environmental science, archaeology, museology, and marketing have all contributed to the theories and techniques on which heritage interpretation is based. The diversity in their understandings about the interaction between visitors and heritage sites was partly lost in the 1980 os due to standardisation processes that narrowed the focus of heritage interpretation, reducing it mainly to communication and education (Staiff, 2014). This is why Tilden's (1977) heritage interpretation precepts from the 1950 s still resonate with contemporary interpretive practice and more practice-oriented interpretation literature (among others Brochu \& Merriman, 2002; Ham, 2013; Ludwig, 2015).

Tilden regards heritage interpretation as ' $[\mathrm{A}] \mathrm{n}$ educational activity which aims to reveal meanings and relationships through the use of original objects, by firsthand experience, and by illustrative media, rather than simply to communicate factual information' (Tilden, 1977 , p. 8). His six principles of interpretation are meant to assist interpreters in achieving this goal. They suggest that heritage interpretation should relate its contents to the experience of the visitor, be provocative and adjusted to children when it addresses them as visitors, and interpret heritage as a whole and not only its parts; finally, interpretation is more than information - it is an art that can be taught.

Although Tilden's definition and principles still echo not only in the practice-oriented works suggested above but also in the influential Ісомоs Charter for the Interpretation and Presentation of Cultural Heritage Sites (ICIP, 2008), recent years have witnessed more critical views of Tilden's work (Silberman, 2013; Silverman \& Ruggles, 2007; Staiff, 2014; Uzzell, 1998). Tilden's approach to heritage interpretation is thus viewed as 'stuck in a rut where how has become more important than the why' (Uzzell, 1998, p. 12; emphasis in original), or just 'a method of face-to-face communication' (Silberman, 2013, p. 22). Tilden is further criticised for 'separating heritage interpretation - as an educational activity for visitors - from interpretation more generally' (Staiff, 2014, p. 34; emphasis in original) and maintaining 'a hierarchical power relationship between the "expert" and the nonexpert, between those with "the knowledge" and those "without the knowledge"' (Staiff, 2014, p. 37). Therefore, it has been suggested that heritage interpretation should be rather approached as a system of representation that aims to facilitate multiple meaning-making as well as meaning-making as a dynamic process (Clarke \& Waterton, 2015; Francesconi, 2018; Staiff, 2014).

\section{Outdoor Interpretive Panels}

Unlike personal interpretation (e.g., guided tours and walks, demonstrations, talks), in which the interpreter 
controls the content, delivery, and order of information presented, interpretive panels communicate through a combination of vivid images and short written texts (Hall et al., 2010; Ham, 2013), and it is the visitors who choose the pace and order of communication when looking at panels, and decide whether to access the information at all or not (Moscardo, Ballantyne, \& Hughes, 2007; Smaldone, 2013). Outdoor interpretive panels help improve the visitor experience in places where the constant presence of staff is not convenient or possible, or where other communication media (e.g., audio guides, brochures) are not available (Hall et al., 2010; Hose, 2006; Moscardo et al., 2007). Heritage sites can feature a single interpretive panel or a series of interpretive displays that can be used as a self-guided trail.

Outdoor interpretive panels support visitors' engagement with heritage sites through the 'official message' of the site incorporated in the panels' contents and also through engagement with that which is beyond the panels' discursive contents: the landscape, the sound, smell, movement, etc. (Clarke \& Waterton, 2015). This is why interpretive panels are widely regarded as important communication mediators that help direct the interactivity of visitors with heritage sites (Tussyadiah, 2014) and encourage suitable visitor behaviours at sensitive natural sites (Hall et al., 2010; Hose, 2006; Light, 1995).

Interpretive panels are, however, also known for their inflexibility (e.g., they are incapable of adjusting to diverse audiences, they cannot be changed or updated easily) and constant need for care and maintenance (Light, 1995; Moscardo et al., 2007). Research has also shown that some interpretive boards are viewed by many while others by only a handful (Hall et al., 2010; Light, 1995). Besides careful placement of interpretative panels, the vividness of the message and overall design seem to play essential roles in assuring the greater visibility and attractiveness of panels. While visitor interest is enhanced through messages that appeal to visitors' empathy and encourage them to take perspective, or through stories, humour and telegraphic thematic titles (Hall et al., 2010; Smaldone, 2013) or metaphors (Smaldone, 2013), the communication appeal of interpretive panels is also en- hanced through design (e.g., background colour, fonts and illustrations, layout) (Hall et al., 2010; Ham, 2013; Moscardo et al., 2007; Smaldone, 2013). The attentionpaying behaviour of visitors to heritage sites is further shaped by their purpose of visit (Light, 1995), the various schemas, past experiences, interests (Hall et al., 2010), or the cultural systems (Clarke \& Waterton, 2015) visitors bring with them to heritage sites.

\section{Intersemiosis and Justification of Method Choice}

Texts targeting tourists tend to exploit more than one semiotic resource to increase their cognitive and emotional effects on the text recipients, i.e., the tourists. There is, however, limited research on intersemiotic relations between the verbal and visual modes in multimodal tourism texts. Following Martinec and Salway's (2005) classification of logico-semantic relations between words and images in static texts, Francesconi (2014) explored the integration of the verbal and visual modes in humorous British postcards often purchased by tourists. She found that the verbal and the visual may exhibit both equal and unequal relative status, the verbal and the visual may be independent of each other or they may complement each other. Using Kress and van Leeuwen's (2006) approach to the analysis of multimodal texts, Maci (2007) examined the composition, interrelation, and interaction between the verbal and visual modes on websites and found that the visual mode often stresses the representational character of places while the verbal enhances the interactive and persuasive aspects of communication with tourists. To our knowledge, the relations between the verbal and visual modes in outdoor interpretive panels have not yet been addressed by research, thus justifying our choice of the method a brief overview of findings on intersemiosis in static texts that will follow.

It was Roland Barthes (1977) who started the critical debate on intersemiosis in his analysis of the relations between the visual and verbal in printed advertisements by claiming that the verbal mode dominated the visual one. In recent years, however, the interplay between the visual and verbal semiotic modes has attracted the attention of multimodal discourse analysists too. Kress and van Leeuwen (2006) suggested that the use of several semiotic modes may reinforce or 


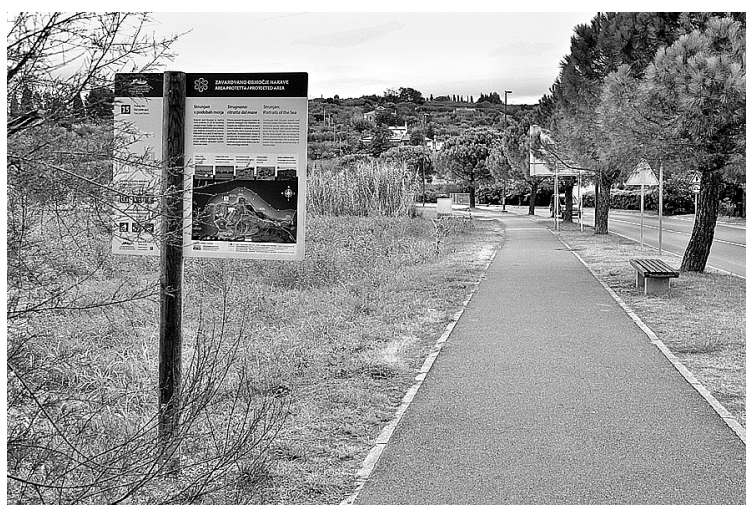

Figure 1 The Interpretive Panel at the Entrance to the Strunjan Natural Park (photo by Šarolta Godnič Vičič)

complement each other, or be hierarchically ordered. Stöckl (2004), in contrast, suggested that the verbal and the visual modes can be integrated in two ways: first, verbal texts and images are most commonly integrated in ways that allow each mode to use its semiotic potential strategically in order to create a combined meaning, and secondly, the integration of the modes takes place when verbal texts emulate the visual (e.g., typography and layout give verbal texts an image quality). Stöckl further suggested that this complex integration of verbal and visual modes involves mode mixing and mode overlapping.

Meaning between the different semiotic modes in multimodal texts is created on the ideational, interpersonal and textual metafunction levels; therefore, intersemiotic relations exist on all three levels (O'Halloran, 2008). The different modes have to create a coherent semantic unit. However, Liu and O'Halloran (2009) warn that the semantic integration of the verbal and visual modes should not be taken for granted: words and images can also merely be placed together. Following Halliday and Hasan (1976) who regard cohesion as a crucial criterion to distinguish text from nontext and thus an essential property of a text, Liu and O'Halloran (2009) suggest that semantic relations between different modalities are realised through intersemiotic cohesive devices and not by the mere linking of the two modes. Liu and O'Halloran thus propose that the semiotic relations between the textual and visual are shown in the intersemiotic texture of multi-

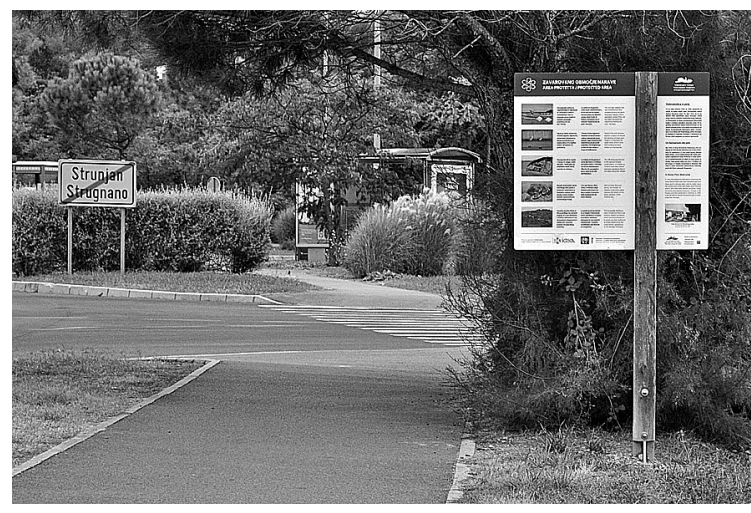

Figure 2 The View of the Interpretive Panel on the Way Out of the Strunjan Natural Park (photo by Šarolta Godnič Vičič)

modal texts, which integrates the two modes through intersemiotic cohesion into a coherent whole.

Liu and O'Halloran (2009) further show that the intersemiotic logical relations (ideational metafunction level) between verbal text and images, or between images, or even between verbal text, image and context can be comparative, additive, consequential, or temporal. When visual and linguistic components share a similar experiential meaning, the different modes are a semiotic reformulation of each other, and their logical relations are defined as being Comparative. They are accompanied by the use of intersemiotic cohesive devices, such as correspondence, parallelism, and contextualisation propensity. When one semiotic component adds new information to another component, the verbal and visual parts convey related, but different messages and the logical relation is defined Additive. In contrast, when one semiotic message enables or determines the other, the logical relation is that of Consequence. A subfield of Consequence can be Contingency when the cause carries only the potential to determine a possibility and the effect is not ensured. Temporal logical relations are procedures that are not realised in mere language but are characterised by multimodality when different procedural steps are represented both verbally and visually.

Using Liu and O'Halloran's (2009) classification of intersemiotic logical relations, the present study sets out to explore the ways in which the verbal and the visual modes form a coherent unit in outdoor inter- 


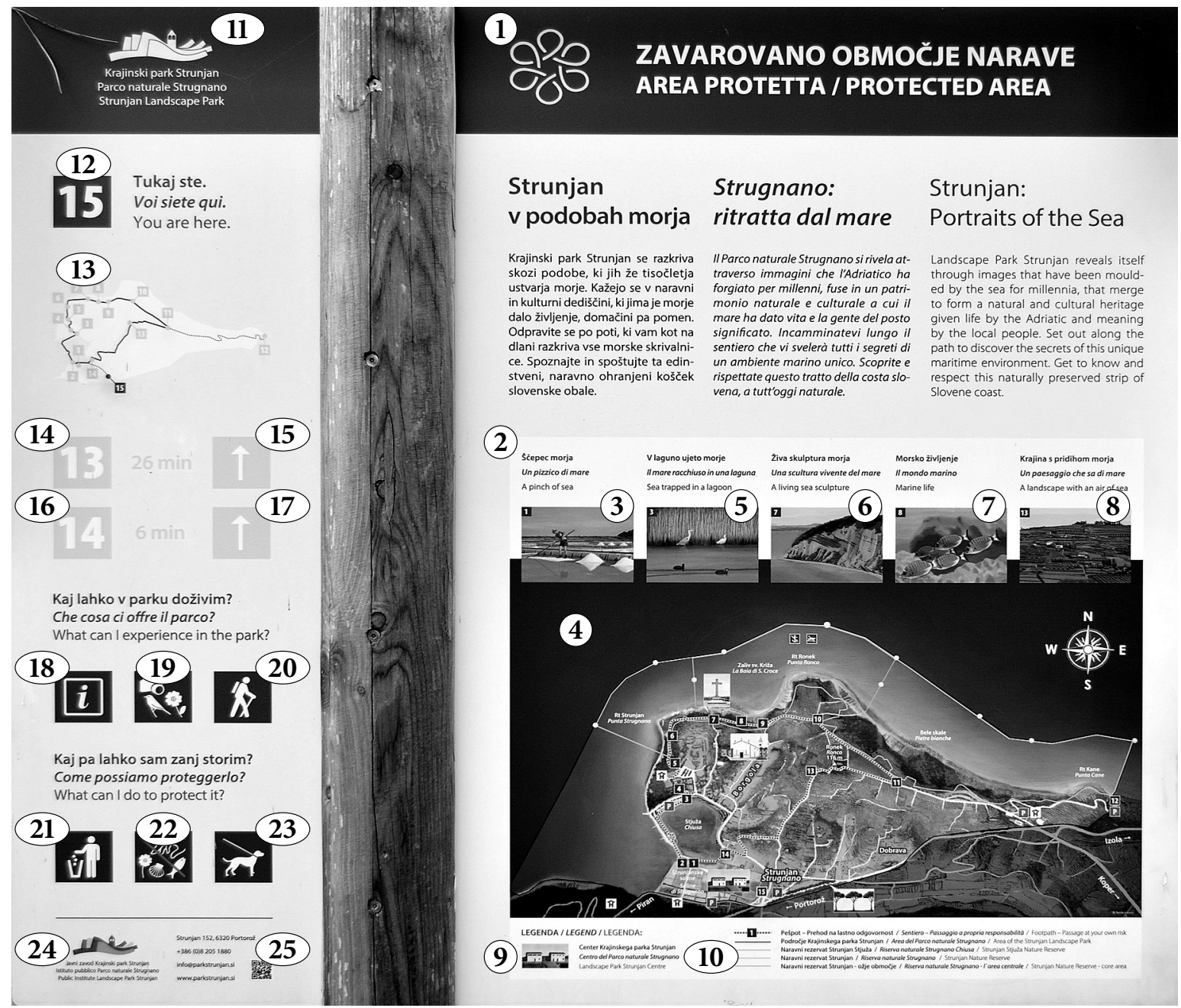

Figure 3 The Front Side of the Interpretive Panel (photo by Šarolta Godnič Vičič)

pretive panels in a protected natural area. The analysis of the verbal and visual elements in multimodal texts tends to be detailed; therefore, a single outdoor interpretive panel will be analysed for intersemiotic logical relations. This modest analysis details the intersemiotic logical relations in an outdoor interpretive panel from the Strunjan Natural Park (Slovenia) that is located at one of the entry points to the natural park. It is the last interpretive panel in the series of fifteen panels that provide interpretation to park visitors who start their thematic tour at the park's visitor centre. However, it is the first interpretive display to those who enter the park from the centre of Strunjan (a small settle- ment). The panel has two sides, and its front is turned towards those who enter the park (Figures 1 and 2).

\section{Findings}

The design of the interpretive panel follows the 'Rules on the marking of protected areas of valuable nature features' ('Pravilnik o označevanju zavarovanih območij naravnih vrednot,' 2002), which determine the design and format of interpretive panels in the protected areas of Slovenia: their shapes, sizes and layout, as well as the use of logos and the designations of protected natural areas. As such, the panel under scrutiny resembles interpretive panels found in other natural 


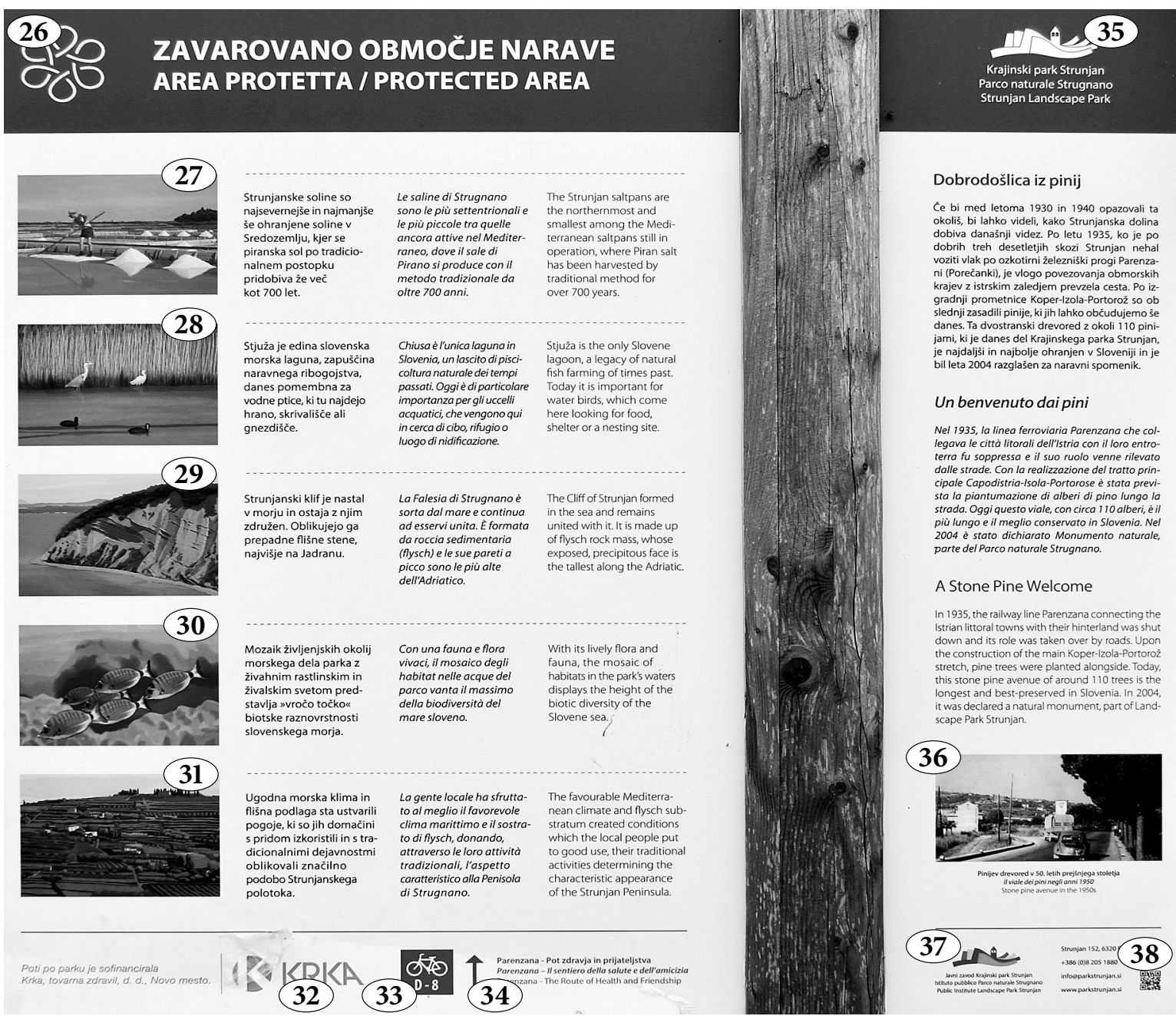

Figure 4 The Back Side of the Interpretive Panel (photo by Šarolta Godnič Vičič)

parks around Slovenia. The interpretive panel consists of two sections (one wider and one narrower) joined (or split) by a pole that carries them. They both share the same background colour and a strip of a dark green header that connects both sections into a visually cohesive unit (Figures 3 and 4 ). There are short texts and various images (illustrations, logos, pictograms, maps) on both sides of the interpretive panel. The texts are presented in three languages: Slovene, Italian (the park is located in a bilingual area of Slovenia where the translation of public texts into Italian is compulsory) and English (often regarded as the lingua franca of tourism communication). The texts in different lan- guages are visually marked by different fonts, but these do not give the texts an image quality in the sense suggested by Stöckl (2004).

The individual intersemiotic logical relations found in the front right section of the panel are presented in detail in Table 1 and those in the front left section of the panel in Table 2. Table 3 summarises the intersemiotic logical relations found in the left section of the back side of the interpretive panel and Table 4 those found in the right section. The texts in English translation are used in the tables for ease of understanding.

The analysis of the intersemiotic logical relations between the verbal texts and images in the interpre- 
Table 1 Intersemiotic Logical Relations on the Front Right Side of the Interpretive Panel

\begin{tabular}{|c|c|c|}
\hline Verbal mode & Visual mode $^{*}$ & Intersemiotic logical relations \\
\hline Protected area & 1 & Comparative - abstraction \\
\hline $\begin{array}{l}\text { Strunjan: Portraits of the Sea. Landscape Park Strunjan reveals itself } \\
\text { through images that have been moulded by the sea for millennia, that } \\
\text { merge to form a natural and cultural heritage given life by the Adriatic } \\
\text { and meaning by the local people. Set out along the path to discover the } \\
\text { secrets of this unique maritime environment. Get to know and respect } \\
\text { this naturally preserved strip of Slovene coast. }\end{array}$ & 2 & Comparative - abstraction \\
\hline A pinch of sea & 3 & Comparative - generality \\
\hline A pinch of sea + Image 3 & 4 & Comparative - abstraction \\
\hline Sea trapped in a lagoon & 5 & Comparative - generality \\
\hline Sea trapped in a lagoon + Image 5 & 4 & Comparative - abstraction \\
\hline A living sea sculpture & 6 & Comparative - generality \\
\hline A living sea sculpture + Image 6 & 4 & Comparative - abstraction \\
\hline Marine life & 7 & Comparative - generality \\
\hline Marine life + Image 7 & 4 & Comparative - abstraction \\
\hline A landscape with an air of sea & 8 & Comparative - generality \\
\hline A landscape with an air of sea + Image 8 & 4 & Comparative - abstraction \\
\hline Landscape Park Strunjan Centre & 9 & Comparative - abstraction \\
\hline Landscape Park Strunjan Centre + Image 9 & 4 & Comparative - generality \\
\hline $\begin{array}{l}\text { Footpath - Passage at your own risk } \\
\text { Area of the Strunjan Landscape Park } \\
\text { Strunjan Stjuža Nature Reserve } \\
\text { Strunjan Nature Reserve } \\
\text { Strunjan Nature Reserve - core area }\end{array}$ & 10 & Comparative - abstraction \\
\hline $\begin{array}{l}\text { Footpath - Passage at your own risk } \\
\text { Area of the Strunjan Landscape Park } \\
\text { Strunjan Stjuža Nature Reserve } \\
\text { Strunjan Nature Reserve } \\
\text { Strunjan Nature Reserve - core area + Image 10 }\end{array}$ & 4 & Comparative - generality \\
\hline
\end{tabular}

tive panel revealed that comparative and additive intersemiotic logical relations prevail; however, the ratio between them differs from section to section of the interpretive panel. It seems that the front right section of the panel aims to represent the park by providing an overview of the park's most prominent features and facilities as well as overall spatial orientation in the park. There are strong intersemiotic logical relations between the verbal and images (illustrations of selected places in the park and maps). Some of them form cohesive units that further form new logical relations (e.g., A pinch of sea + Image in Table 1). However, the map in this section also showed a few loose ends: three illustrations of places in the park that are embedded in the map seem independent from the verbal texts and form no intersemiotic logical relations with them. Should a visitor read the text about the pine avenue on the back side of the interpretive panel, one of these images (i.e., the one with the row of pines) would form a logical relation with that text, but this 
Table 2 Intersemiotic Logical Relations in the Left Front Part of the Interpretive Panel

\begin{tabular}{lll}
\hline Verbal mode & \multicolumn{1}{l}{ Visual mode $^{\star}$} & Intersemiotic logical relations \\
\hline Strunjan Landscape Park & 11 & Comparative - abstraction \\
\hline You are here & 12,13 & Additive \\
\hline 26 min & 14,15 & Additive \\
\hline 6 min & 16,17 & Additive \\
\hline What can I experience in the park? & $18,19,20$ & Additive \\
\hline What can I do to protect it? & $21,22,23$ & Additive \\
\hline Public Institute Landscape Park Strunjan & 24 & Comparitive - abstraction \\
\hline $\begin{array}{l}\text { Strunjan 152, 6320 Portorož, +386 (o)8 205 1880, } \\
\text { info@parkstrunjan.si, www.parkstrunjan.si }\end{array}$ & 25 & Comparitive - abstraction \\
\hline Notes * See Figure 3. & & \\
\hline
\end{tabular}

Table 3 Intersemiotic Logical Relations in the Left Back Part of the Interpretive Panel

\begin{tabular}{|c|c|c|}
\hline Verbal mode & Visual mode $^{*}$ & Intersemiotic logical relations \\
\hline Protected area & 26 & Comparative - abstraction \\
\hline $\begin{array}{l}\text { The Strunjan saltpans are the northernmost and smallest among the } \\
\text { Mediterranean saltpans still in operation, where Piran salt has been } \\
\text { harvested traditional method for over } 700 \text { years. }\end{array}$ & 27 & Additive \\
\hline $\begin{array}{l}\text { Stjuža is the only Slovene lagoon, a legacy of natural fish farming of } \\
\text { times past. Today it is important for water birds, which come here look- } \\
\text { ing for food, shelter or a nesting site. }\end{array}$ & 28 & Additive \\
\hline $\begin{array}{l}\text { The Cliff of Strunjan formed in the sea and remains united with it. It } \\
\text { is made up of flysch rock mass, whose exposed, precipitous face is the } \\
\text { tallest along the Adriatic. }\end{array}$ & 29 & Additive \\
\hline $\begin{array}{l}\text { With its lively flora and fauna, the mosaic of habitats in the park's wa- } \\
\text { ters displays the height of the biotic diversity of the Slovene sea. }\end{array}$ & 30 & Additive \\
\hline $\begin{array}{l}\text { The favourable Mediterranean climate and flysch substratum created } \\
\text { conditions which the local people put to good use, their traditional } \\
\text { activities determining the characteristic appearance of the Strunjan } \\
\text { Penninsula. }\end{array}$ & 31 & Additive \\
\hline Poti po parku je sofinancirala Krka, tovarna zdravil, d.d., Novo mesto & 32 & Comparitive - abstraction \\
\hline Parenzana - The Route of Health and Friendship & 33,34 & Comparative - abstraction \\
\hline
\end{tabular}

Notes * See Figure 4 .

logical relation seems weaker, less obvious and subject to greater chance.

In addition to reinforcing the identity of the park, the intersemiotic logical relations between the verbal and the visual in the left section of the front side of the interpretive panel also direct visitors' explorations of the park and encourage particular visitor behaviour.

The back side of the interpretive panel mainly aims to provide new information about the heritage aspects of the park and its history. The intersemiotic logical relations between the verbal and the visual are those of Addition. The park's identity is again reinforced with comparative relations of Abstraction (the logo). Information is also provided on a sponsor and visitors on bicycles are given directions. The photo of the pine avenue from the 1950 is slightly vague, but its logical re- 
Table 4 Intersemiotic Logical Relations in the Right Back Part of the Interpretive Panel

\begin{tabular}{lll}
\hline Verbal mode & Visual mode & Intersemiotic logical relations \\
\hline Strunjan Landscape Park & 35 & Comparative - abstraction \\
\hline $\begin{array}{l}\text { A Stone Pine Welcome. In 1935, the railway line Parenzana connect- } \\
\text { ing the Istrian littoral towns with their hinterland was shut down and }\end{array}$ & 36 & Additive \\
$\begin{array}{l}\text { its role was taken over by roads. Upon the construction of the main } \\
\text { Koper-Izola-Portorož stretch, pine trees were planted alongside. To- } \\
\text { day, this stone pine avenue of around 110 trees is the longest and best- } \\
\text { preserved in Slovenia. In 2004, it was declared a natural monument, } \\
\text { part of Landscape Park Strunjan. }\end{array}$ & \\
\hline Stone pine avenue in the 1950s & 36 & \\
\hline Public Institute Landscape Park Strunjan & 37 & Comparative - generality \\
\hline $\begin{array}{l}\text { Strunjan 152, 6320 Portorož, +386 (o)8 205 1880, } \\
\text { info@parkstrunjan.si, www.parkstrunjan.si }\end{array}$ & 38 & Comparitive - abstraction \\
\hline Notes & & Comparitive - abstraction
\end{tabular}

Notes * See Figure 4.

lation with the text below helps to diminish the photo's vagueness.

\section{Discussion and Conclusions}

Outdoor interpretive panels are studied in this paper as multimodal texts. Using Liu and O'Halloran's (2009) framework for intersemiotic logical relations between the verbal and the visual, we aimed to reveal the cohesive ties that connect both modes in outdoor interpretive panels into a cohesive, meaningful unit.

The analysis showed that the prevailing intersemiotic logical relations in interpretive panels are those of Comparison and Addition. Both can be deployed to create representations of the heritage site as space and place, direct the movement and behaviour of visitors, and also reinforce the identity of the park both as a heritage site and as a protected area managed and regulated by park authorities. The intersemiotic logical relations of Addition convey new information about the heritage site that aims to grab visitors' attention and help them form emotional and cognitive attitudes/relations with the park. Furthermore, intersemiotic logical relations of Comparison tend to represent the park in space and raise interest in experiencing the park further by elaborating familiar meanings and reformulating them at different levels of abstraction and generality.

Combinations of Comparative and Additive intersemiotic logical relations can help design outdoor in- terpretive panels that reflect the various communication aims of interpretive panels. The analysis of the intersemiotic logical relations between the verbal and visual can be a useful tool for teams that design interpretive panels. The analysis not only reveals loose ends between texts and images but also assists in strengthening the cohesive ties between them and creating coherent meanings.

Intersemiotic logical relations between the verbal and visual resources in interpretive panels are not the only cohesive devices in them. Intersemiotic relations also exist on the experiential and textual metafunction levels that should require future attention. The verbal texts and the images seem to have strong cohesive ties not only with each other but also with the extradiscursive features of the context in which interpretive panels are placed. The fact that visitors control the sequence of information, the choice of content and the investment of time, makes the cohesion of the verbal, the visual and context of pivotal importance and worthy of further research.

\section{References}

Barthes, R. (1977). Image, music, text. London, England: Fontana Press.

Brochu, L., \& Merriman, T. (2002). Personal interpretation: Connecting your audience to heritage resources. Fort Collins, T x: National Association for Interpretation.

Clarke, A., \& Waterton, E. (2015). A journey to the heart. Landscape Research, 40(8), 971-992. 
Francesconi, S. (2014). Reading tourism texts: A multimodal analysis. Buffalo, NY: Channel View Publications.

Francesconi, S. (2018). Heritage discourse in digital travel video diaries. Trento, Italy: Tangram Edizioni Scientifiche.

Fritsch, J. (Ed.) (2011). Routledge research in museum studies (Vol. 2) New York, Ny: Routledge.

Hall, T. E., Ham, S. H., \& Lackey, B. K. (2010). Comparative evaluation of the attention capture and holding power of novel signs aimed at park visitors. Journal of Interpretation Research, 15(1), 15-36.

Halliday, M. A. K., \& Hasan, R. (1976). Cohesion in English (English Language Series 29). Abingdon, Ny: Longman.

Ham, S. H. (2013). Interpretation: Making a difference on purpose. Golden, co: Fulcrum Publishing.

Hillier, B., \& Tzortzi, K. (2006). Space syntax. In S. Macdonald (Ed.), A companion to museum studies (Blackwell Companions in Cultural Studies 12, pp. 282-301). Oxford, England: Blackwell.

Hose, T. A. (2006). Geotourism and Interpretation. In R. K. Dowling \& D. Newsome (Eds.), Geotourism (pp. 221241). Amsterdam, The Netherlands: Elsevier Butterworth-Heinemann.

ICIP (2008). ICOMOS charter for the interpretation and presentation of cultural heritage sites. Retrieved from http://icip.icomos.org/downloads/ICOMOS

_Interpretation_Charter_ENG_04_10_08.pdf

Kress, G. R., \& van Leeuwen, T. (2006). Reading images: The grammar of visual design (2nd). London, England: Routledge.

Light, D. (1995). Visitors' use of interpretive media at heritage sites. Leisure Studies, 14(2), 132-149.

Liu, Y., \& O’Halloran, K. L. (2009). Intersemiotic texture: Analyzing cohesive devices between language and images. Social Semiotics, 19(4), 367-388.

Ludwig, T. (2015). The interpretive guide: Sharing heritage with people. Werleshausen, Germany: Bildungswerk Interpretation.

Maci, S. M. (2007). Virtual touring: The web-language of tourism. Linguistica e Filologia, 25, 41-65.

Martinec, R., \& Salway, A. (2005). A system for image-text relations in new (and old) media. Visual Communication, 4(3), 337-371.

Moscardo, G., Ballantyne, R., \& Hughes, K. (2007). Designing interpretive signs: Principles in practice. Golden, co: Fulcrum Publishing.

Moser, S. (2010). The devil is in the detail: Museum displays and the creation of knowledge. Museum Anthropology, $33(1), 22-32$.
O’Halloran, K. L. (2008). Systemic functional-multimodal discourse analysis (SF-MDA): Constructing ideational meaning using language and visual imagery. Visual Communication, $7(4)$, 443-475.

Pravilnik o označevanju zavarovanih območij naravnih vrednot. (2002). Uradni list Republike Slovenije, No. 117.

Psarra, S. (2005). Spatial culture, way-finding and the educational message: The impact of layout on the spatial, social and educational experiences of visitors to museums and galleries. In S. MacLeod (Ed.), Reshaping Museum Space (pp. 92-108). London, England: Routledge.

Silberman, N. A. (2013). Understanding heritage: Perspectives in heritage studies. In M.-T. Albert, R. Bernecker, \& B. Rudolff (Eds.), Understanding heritage: Perspectives in heritage studies (pp. 21-33). Berlin, Germany: De Gruyter.

Silverman, H., \& Ruggles, F. D. (2007). Cultural heritage and human rights. In H. Silverman \& D. F. Ruggles (Eds.), Cultural heritage in a globalized world: Cultural heritage and human rights (pp.3-22). New York, NY: Springer.

Smaldone, D. (2013). Planning interpretive and education programs for wetlands. In J. T. Anderson \& C. A. Davis (Eds.), Wetland Techniques (Vol. 3, pp. 229-255). Dordrecht, The Netherlands: Springer.

Staiff, R. (2014). Re-imagining heritage interpretation: Enchanting the past-future. Farnham, England: Ashgate.

Stöckl, H. (2004). In between modes: Language and image in printed media. In E. Ventola, C. Charles, \& M. Kaltenbacher (Eds.), Perspectives on multimodality (pp. 9-30). Amsterdam, The Netherland: John Benjamins.

Tilden, F. (1977). Interpreting our heritage. Chapel Hill, NC: The University of North Carolina Press.

Tussyadiah, I. (2014). Toward a theoretical foundation for experience design in tourism. Journal of Travel Research, $53(5), 543-564$.

Uzzell, D. (1998). Interpreting our heritage: A theoretical interpretation. In D. Uzzell \& R. Ballantyne (Eds.), Contemporary issues in heritage and environmental interpretation: Problems and prospects (pp. 11-25). Norwich, England: Stationery Office.

Ward, C. W., \& Wilkinson, A. E. (2006). Conducting meaningful interpretation: A field guide for success. Golden, co: Fulcrum Publishing.

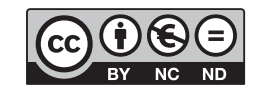

This paper is published under the terms of the Attribution- NonCommercial-NoDerivatives 4.0 International (CC B Y-NC-ND 4.0) License. 